\title{
An Expert System-Based Evaluation of Civics Education as a Means of Character Education Based on Local Culture in the Universities in Buleleng
}

\author{
Dewa Bagus Sanjaya ${ }^{1}$ \\ Lecturer of Civics Education \\ Ganesha University of Education \\ Singaraja, Bali, Indonesia
}

\author{
Dewa Gede Hendra Divayana ${ }^{2}$ \\ Lecturer of Information Technology Education \\ Ganesha University of Education \\ Singaraja, Bali, Indonesia
}

\begin{abstract}
Civics education as a means of character education based on local culture has the mission to develop values and attitudes. In the educational process, various strategies and methods of value education can be used. In Civics Education characters are developed as the impact of education and also as its nurturing effect. Meanwhile, other subjects, which formally have the major mission other than character development have to develop activities that have the nurturing effect of character development in the students. However, in the educational process this has not run well. Hence, there is a need to evaluate educational programs at public as well as private universities in Buleleng regency. One of the evaluation techniques that can be used is the CIPP model combined with certainty factor method in expert system. The CIPP Model can evaluated the Civics education processes at all the public and private universities in Buleleng regency objectively, especially in probing local culture in character educational development. Meanwhile, the certainty factor method is used to determine the extent or degree of certainty of a component being evaluated in Civics educational processes.
\end{abstract}

Keywords-Evaluation of Civics Education; Character; Local culture; Expert System; Certainty Factor

\section{INTRODUCTION}

Civics Education (PKn) has a very vital status and very strategic in fostering patriotism, nationalism and in nation and carácter building. However, in its implementation, it is very susceptible to practical political bias of the authority that tends to be an instrument used by the authority rather a means of the nation character building. The same thing occurs in developing countries as stated by Cogan (1998). He states: It (citizenship education) has also often reflected the interests of those in power in a particular society and thus has been a matter of indoctrination and the establishment of ideological hegemony rather than of education [1].

Various efforts have been done such discussion, conference, sarasehan, and other activities of that are like them that are vercommon all over the regions of Indonesia, a strong indicator that all of the components of the nation have a strong national commitment. However, there is a need for a comprehensive national policy, that is coherent, and sustainable that encourages the government to take an initiative to prioritize the nation character development. This implies that every effort of development has to always be directed to give a positive effect to the nation character development. In this modern world, as stated by Lickona (1991) we tend to forget the virtuous life, including in it selforiented virtues or virtues to oneself, such as self control and moderation; and other-oriented virtues such a generosity and compassion or willingness to share and feel virtues[2].

As the consequence, the nation character building has a very wide scope and a multidimensional urgency level. Winataputra (2006) stresses that the nation character development has to be focused on three broad levels.,i.e., (1) to foster and strengthen the nation identity, (2) to keep the Unification of Republic of Indonesia (NKRI), and (3) to develop Indonesian man and womans and Indonesian community that have good ethics and a nation with dignity[3].

Civics Education as a means of character education based on local culture has the mission to develop values and attitudes. In the educational process it can use various strategies and value education methods. Civics Education develop character as the effect of the education and also as the dampak pengiring. Meanwhile, other subjects which formally have the major missions other than the character development, have to develop activities that have dampak pengiring of the development of character in the students. However, the education process has not run well.

For that reason, there is a need for evaluating the educational processes at the public and private universities in Buleleng regency. One of the techniques of evaluation that can be used is CIPP model combined with certainty factor in the expert system. The CIPP Model can evaluate the Civics Education process in all the public and private universities in Buleleng regency objectively, especially in probing the local culture in developing character education.

Meanwhile certainty factor method is used to determine the extent of certainty of one component which is being evaluated in the Civics Education process.

\section{LITERATURE REVIEW}

\section{A. Evaluation}

In [4], evaluation is a systematic collection of fact to determine whether in fact there is a change in students and establish the extent of change in the individual student. 
In [5], Evaluation is an activity in collecting, analysing, and presenting information about an object of research and the results can be used to take a decision. In [6], Evaluation can be defined as the determination of conformity between the results achieved and the objectives to be achieved. In [7], Evaluation is an activity to gather information about the workings of something, which then the information is used to determine the appropriate alternative in making decisions.

From the opinions of the above can be concluded in general that the evaluation is an activity for data collecting, data analysing and data presenting into information about a particular object under study so that the results can be used to take a decision.

\section{B. CIPP Model}

In [8], the CIPP evaluation there are four components that must be passed is the evaluation of the component context, the evaluation of input component, the evaluation of process components, and the evaluation of product components.

In [9], CIPP model is a model in its activities through four stages of evaluation are: evaluation of the component context, input, process and product.

From the above opinions can be concluded in general that the CIPP model is a model that essentially has four stages of evaluation are: evaluation of the component context, component input, component process and component product.

\section{Expert System}

In [10], an expert system is considered as a computer simulation of human expertise. In [11], Expert System is a program that behaves like some experts, and have limited domains of application in certain problems.

In [12], an expert system is a computer program that stimulates an evaluation and behaviors of human or organization that has knowledge and experiences of experts in a certain field.

In [13], Expert system is an artificial intelligence system that combines the basics of knowledge and inferential motor in such a way that it can adopt the ability of an expert into the computer, so that the computer can solve problems such as those often done by experts.

In [14], Expert system is made only in certain knowledge domain to approximate human ability only in one field.

In [15], Expert system is a kind of contemporary software that makes computer more useful than before.

From the various opinion above it can be concluded that artificial intelligence that combines the basics of knowledge and inferential machine in order it can adopt the ability experts into an instrument to solve problems like what experts do.

\section{Certainty Factor $(C F)$}

Certainty Factor $(C F)$ is one of the methods used to show the extent of certainty of facts or rules. 16]. The notation of certainty factor caused by one fact is as follows:

$\mathrm{CF}[\mathrm{H}, \mathrm{E}]=\mathrm{MB}[\mathrm{H}, \mathrm{E}]-\mathrm{MD}[\mathrm{H}, \mathrm{E}]$ In which:
$\mathrm{CF}[\mathrm{H}, \mathrm{E}]=$ certainty/ confidence factor about hypothesis $\mathrm{H}$ towards fact $\mathrm{E}$ (between -1 and 1)

$\mathrm{MB}[\mathrm{H}, \mathrm{E}]=$ the extent of confidence towars hypothesis $\mathrm{H}$ with fact $\mathrm{E}$ (between 0 and 1)

$\mathrm{MB}[\mathrm{H}, \mathrm{E}]=$ the extent of nonconfidence towards hypothesis $\mathrm{H}$ with fact $\mathrm{E}$ ( between 0 and 1 )

Meanwhile factor notation of certainty facts that are caused by more than one fact is as follows:

$\mathrm{CF}\left[\mathrm{H}, \mathrm{E} 1^{\wedge} \mathrm{E} 2\right]=\mathrm{MB}\left[\mathrm{H}, \mathrm{E} 1^{\wedge} \mathrm{E} 2\right]-\mathrm{MD}\left[\mathrm{H}, \mathrm{E} 1^{\wedge} \mathrm{E} 2\right] \ldots \ldots . .2$

In which:

$\mathrm{MB}[\mathrm{H}, \mathrm{E} 1 \wedge \mathrm{E} 2]=\mathrm{MB}[\mathrm{H}, \mathrm{E} 1]+\mathrm{MB}[\mathrm{H}, \mathrm{E} 2]^{*}(1-\mathrm{MB}[\mathrm{H}, \mathrm{E} 1])$

$\mathrm{MD}[\mathrm{H}, \mathrm{E} 1 \wedge \mathrm{E} 2]=\mathrm{MD}[\mathrm{H}, \mathrm{E} 1]+\mathrm{MD}[\mathrm{H}, \mathrm{E} 2]^{*}(1-\mathrm{MD}[\mathrm{H}, \mathrm{E} 1])$ In which:

$\mathrm{CF}\left[\mathrm{H}, \mathrm{E} 1^{\wedge} \mathrm{E} 2\right]=$ certainty/confidence factor about hypothesis $\mathrm{H}$ towards fact $\mathrm{E} 1$ and $\mathrm{E} 2$ (between -1 and 1)

$\mathrm{MB}\left[\mathrm{H}, \mathrm{E} 1^{\wedge} \mathrm{E} 2\right]=$ the extent of confidence towards hypothesis $\mathrm{H}$ with facts $\mathrm{E} 1$ and $\mathrm{E} 2$ (between 0 and 1)

$\mathrm{MB}\left[\mathrm{H}, \mathrm{E} 1^{\wedge} \mathrm{E} 2\right]=$ the extent of nonconfidence towards hypothesis $\mathrm{H}$ with facts $\mathrm{E} 1$ and $\mathrm{E} 2$ (between 0 and 1)

\section{MethodOLOGY}

\section{A. Object dan Research Site}

1) Research Object is Civics Education program as the means for character education.

2) Research Site at universities in Buleleng regencies.

\section{B. Data Type}

In this research, the authors use primary and secondary data, quantitative and qualitative data.

\section{Data Collection Techniques}

In this research, the authors use data collection techniques such as observation, interviews, and documentation.

\section{Evaluation Model}

Evaluation model used in this research is CIPP model and combined with the certainty factor method.

\section{E. Aspect of Evaluation}

The aspects that were evaluated in Civics Education can be seen in the table of evaluation criteria as follows.

\section{TABLE I. EVALUATION CRITERIA}

\begin{tabular}{|c|c|c|}
\hline No & Component & Aspects \\
\hline \multirow[t]{2}{*}{1.} & \multirow[t]{2}{*}{ Context } & $\begin{array}{l}\text { The status of Civics Education in university } \\
\text { curriculums }\end{array}$ \\
\hline & & Visions and Missions of Civics Education \\
\hline \multirow{3}{*}{2.} & \multirow{3}{*}{ Input } & Description of Civics Education \\
\hline & & Human resources \\
\hline & & Infrastructures and facilities \\
\hline \multirow{3}{*}{3.} & \multirow{3}{*}{ Process } & Planning for Civics Education \\
\hline & & Implementation of Civics Education \\
\hline & & Assessment of Civics Education \\
\hline \multirow[b]{2}{*}{4.} & \multirow[b]{2}{*}{ Product } & Effect of the implementation of Civics Education \\
\hline & & $\begin{array}{l}\text { Results expected from the implementation of } \\
\text { Civics Education }\end{array}$ \\
\hline
\end{tabular}




\section{RESULT AND DISCUSSION}

A. Result

1) Result of analysis from CIPP Model

The result of analysis using CIPP model can be explained as follows:

a) In the Context components: Civics Education at universities in Buleleng regency has followed the curriculum written in each respective institution.

b) In the Input components: Civics Education at universities in Buleleng regency has followed the descriptions offered by the Ministry of Research, Technology and Higher Education. The educational background of the lecturers of Civics Education at the universities in Buleleng regency is minimally Master degree in the Department of Pancasila and Civics Education Department.

c) In the Process components: The universities in Buleleng regency have appreciated, accommodated, and internalized local culture based character education through Civics Education that is stipulated in the curriculum. In the effort to internalize and transform character education in the educational process, the lecturers of Civics Education have used multi-approaches multi-strategies, and multi-methods. One of the dominant approaches practiced in education is contextual approach.

d) In the Product components: The realization of contextual approach is the probing of local wisdoms of Baliese community that can be used as the model in developing character education, which among other things include:

i. Tri hita karana ideology terminologically, the concept of tri hita karana comes from the word tri that means three; hita prosperity, happiness; and karana that means source of cause. Thus tri hita karana means three sources of cause of the prosperity and happiness in life and the life of all creatures of God [17]. The prosperity of life can be realized if there is a harmony between human beings and the creator (God), human beings and their fellow human beings, and human beings and the natural environment. Tri hita karana then developed into the teaching of harmony, and balance and at the same time also the interdependence in a life system. This is based on the awareness that the universe is a complexity of elements which form a system of universe. The major principle of balance and harmony in the relationship between human beings and God, human beings and their fellow human beings, and human beings and the natural environment becomes the philosophy of life of the Balinese community, both in developing the system of knowledge, the patterns of behavior, attitudes, values, tradition, art, etc. This is very useful for Balinese community in the effort to meet the needs and solving problems of life that are faced both in interpersonal and intergroup relations. Since these major principles become the basis for the development of attitudes, values, behaviors, values, and social relationship in Balinese community, and these principles have been internalized and institutionalized in the social life of the Balinese social structure. At the individual level, Balinese as the microcosmic environment (buana alit), for example, it is believed that human life is a dynamic manifestation of relational motion of atman (spirit), prana (power, strength), and sarira (physical body element). The broader social institutions of the Balinese is the environment of the macrocosmic environment of the individual, from the family organization as the smallest social institution, group of kinship (clan), desa pakraman, subak organization, seke teruna-teruni, seke manyi, seke gong, up to the Balinese community as a whole, apply the same pattern in creating the harmony among the three elements above in developing a daily cultural activity by reinforcing the concepts of parhyangan, pawongan, dan palemahan [18]. Through the concept of parahyangan, Balinese man and woman and Balinese community believe that everything in this world including human beings come from and because of this will come to God. This awareness encourages Balinese man and woman and Balinese community to improve their crada dan bhakti (belief and devotion) to God (Ida Sang Hyang Widhi Waca) in accordance with the teachings of the religion, beliefs and traditions that they practice in life. It is not surprising since at each level of the Balinese social institution are erected holy places of worshipping God the places that function as a means for human beings to relate themselves with God. It is also believed that all cultural products and human civilization and also Balinese community are created as offerings to God and spirits that are often called yadnya. We can see, for example, from the religiously symbolic meanings hidden and contained in the implementation of yadnya, the traditional or customary activities, and Balinese art and cultural works. Through the concept of pawongan, then, Balinese man and woman and Balinese community believe that naturally, human beings are equal as the creature and servants of God who are cultured and as a consequence, need to develop the attitude of asah, asih, dan asuh and work together to achieve the goal of human life, humans as social creature. The third element from the tri hita karana teaching is palemahan. Through this concept, Balinese man and Balinese community believe that there is a need for a harmonic relationship between human being and the other elements and powers of nature. Such relationship is symbolized with the expression "kadi manik ring cecepu" (like a baby in its mother's womb) [19]. Balinese man and woman are aware that human beings cannot be separated from the nature, since it is the nature that gives humans prosperity. Even they believe that the elements and power of this nature are the siblings of human beings as symbolized that every baby born it is always together with its four siblings (placenta, amniotic fluid, lamas/ placenta wrapping pembunga kus arib-ari and blood). The manifestation of love of Balinese man and woman towards these elements and powers of the universe is expressed in a sacrifice ceremony to bhuta (butha yadnya), in addition 
to actively maintaining and preserving the natural environment.

ii. The tat twam asi teaching which literally means "he or she is you too". With the teaching of tat twam asi is meant that actually all human beings are one and the same creature of God. Thus, it is believed that to help other people means to help oneself, and to hurt others means to hurt oneself too [20]. Balinese man and woman believe and appreciate the differences in the characteristics of the life of human beings as the result of rwabhineda ties themselves.

iii. The concept of Nyama braya. Nyama braya is a concept that comes from the community cultural system. The cultural value system is the highest level and the most abstract of the customs. This is caused by the fact that the cultural values are concepts about what is life in the thinking of most of the people of a particular community about what they consider valuable, important and correct that have to be done in the life in this world, these high values are expected to function as a guide that gives a direction and orientation to the people of Bali, both those who live in complex towns or cities and those who live in villages and mountains with a simple life, there are some cultural values that are related with each other to form a system, and this system serves as a guideline from the ideal concepts in the culture as a strong motif for the direction in life of the community members. Nyama braya is the application of the concept of rukun. The word rukun contains the meanings close, peaceful, and do not fight with each other, thus it is likened to the life of a couple in a family that is rukun, it means harmonious and peaceful. The most essential meaning of kerukunan hidup is to protect harmony in the community that is multicultural by fostering the attitude of mutual respect and mutual complementing since to be aware that human beings are the best of all the creatures that God created. There is no absolutely perfect human being (tan hana wong swasta nulus). Human beings need the help from each other (paras paros sarpanaya, salunglung sabhayantaka, saling asah, asih dan asuh).

Differences/varieties are a must (rwabhineda). The awareness in practicing the teaching of religion is tested when one is aware of life plurality (tattwamasi). To show an attitude towards differences as human right of each individual (sarva santhu niramayah) as long as it does not violate the other's right.

\section{2) Result of Analysis of Certainty Factor Method}

TABLE II. SCORE OF DETERMINING THE DEGREE OF CERTAINTY OF A COMPONENT EVALUATED IN CIVICS EDUCATION PROCESS

\begin{tabular}{|c|c|c|c|c|c|c|c|c|c|c|c|}
\hline \multirow{3}{*}{ No } & \multirow{3}{*}{$\begin{array}{l}\text { Respon- } \\
\text { Dent }\end{array}$} & \multicolumn{8}{|c|}{ Component of Evaluation } & \multicolumn{2}{|c|}{ CF Value } \\
\hline & & \multicolumn{2}{|c|}{$\mathrm{C}(\%)$} & \multicolumn{2}{|c|}{ I $(\%)$} & \multicolumn{2}{|c|}{$\mathbf{P}(\%)$} & \multicolumn{2}{|c|}{$\mathbf{P}(\%)$} & \multirow{2}{*}{ Dec } & \multirow{2}{*}{$\%$} \\
\hline & & B & $\mathbf{U}$ & B & $\mathbf{U}$ & B & $\mathbf{U}$ & B & $\mathbf{U}$ & & \\
\hline 1 & R1 & 90 & 10 & 98 & 2 & 95 & 5 & 98 & 2 & 0,82 & 82 \\
\hline 2 & $\mathrm{R} 2$ & 97 & 3 & 99 & 1 & 99 & 1 & 99 & 1 & 0,94 & 94 \\
\hline 3 & R3 & 95 & 5 & 95 & 5 & 95 & 5 & 99 & 1 & 0,80 & 80 \\
\hline 4 & $\mathrm{R} 4$ & 95 & 5 & 95 & 5 & 95 & 5 & 99 & 1 & 0,80 & 80 \\
\hline 5 & R5 & 97 & 3 & 99 & 1 & 99 & 1 & 99 & 1 & 0,94 & 94 \\
\hline 6 & R6 & 97 & 3 & 99 & 1 & 99 & 1 & 99 & 1 & 0,94 & 94 \\
\hline 7 & R7 & 95 & 5 & 95 & 5 & 95 & 5 & 99 & 1 & 0,80 & 80 \\
\hline 8 & R8 & 90 & 10 & 98 & 2 & 95 & 5 & 98 & 2 & 0,82 & 82 \\
\hline 9 & R9 & 97 & 3 & 99 & 1 & 99 & 1 & 99 & 1 & 0,94 & 94 \\
\hline 10 & R10 & 95 & 5 & 95 & 5 & 95 & 5 & 99 & 1 & 0,80 & 80 \\
\hline 11 & R11 & 97 & 3 & 99 & 1 & 99 & 1 & 99 & 1 & 0,94 & 94 \\
\hline 12 & R12 & 90 & 10 & 98 & 2 & 95 & 5 & 98 & 2 & 0,82 & 82 \\
\hline 13 & R13 & 97 & 3 & 99 & 1 & 99 & 1 & 99 & 1 & 0,94 & 94 \\
\hline 14 & R14 & 95 & 5 & 95 & 5 & 95 & 5 & 99 & 1 & 0,80 & 80 \\
\hline 15 & R15 & 95 & 5 & 95 & 5 & 95 & 5 & 99 & 1 & 0,80 & 80 \\
\hline
\end{tabular}

Explanation:

B : The extent of belief/faith in component

$\mathrm{U}$ : The extent of disbelief/Unfaith in component

C : Context component

I : Input component

$\mathrm{P} \quad$ : Process component

P : Product component

\section{B. Discussion}

1) Working Principle of Certainty Factor $(C F)$

The working principle of certainty factor $(\mathrm{CF})$ is by doing a substraction between the extent of disbelief in hypothesis $\mathrm{H}$ with Fact $\mathrm{E}(\mathrm{MB}[\mathrm{H}, \mathrm{E}])$ and the extent of belief in hypothesis $\mathrm{H}$ with fact $\mathrm{E}(\mathrm{MD}[\mathrm{H}, \mathrm{E}])$. In addition, there is also the principle of certainty factor (CF) that is used to determine a hypothesis based on some evidence, i.e., by substracting the extent of disbelief in hypothesis $\mathrm{H}$ with facts $\mathrm{E} 1$ and $\mathrm{E} 2 \mathrm{MB}$ $\left.\left[\mathrm{H}, \mathrm{E} 1^{\wedge} \mathrm{E} 2\right]\right)$ terhadap the extent of belief in hypothesis $\mathrm{H}$ with facts $\mathrm{E} 1$ and $\mathrm{E} 2\left(\mathrm{MD}\left[\mathrm{H}, \mathrm{E} 1^{\wedge} \mathrm{E} 2\right]\right)$.

\section{2) Certainty Factor (CF)Working Procedures}

Referring to the result in table II above, for respondent RI then its Certainty Factor (CF) following the following procedures:

a) Determining Certainty Factor (CF) of the success of the context component caused by the aspect of Civics Education status in the curriculum of Higher Learning, and Vision and Missions of Civics Education Course

$\mathrm{CF}[\mathrm{H}, \mathrm{E}]=\mathrm{MB}[\mathrm{H}, \mathrm{E}]-\mathrm{MD}[\mathrm{H}, \mathrm{E}]$

$\mathrm{CF}[\mathrm{H}, \mathrm{E}]=0.9-0.1=0.8$ 
b) Determining Certainty Factor (CF) of the success of the input component caused by the aspect of description of Civics Education, human resources, infrastructure and facilities

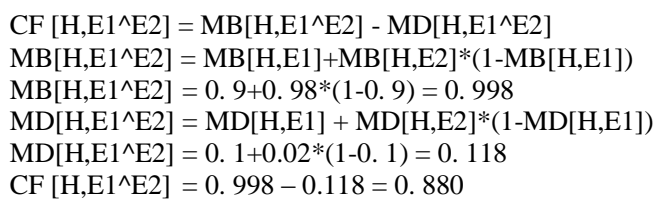

c) Determining Certainty Factor (CF) of the success of the process component caused by the aspect of planning of Civics Education, implementation of Civics Education and assessment of Civics Education

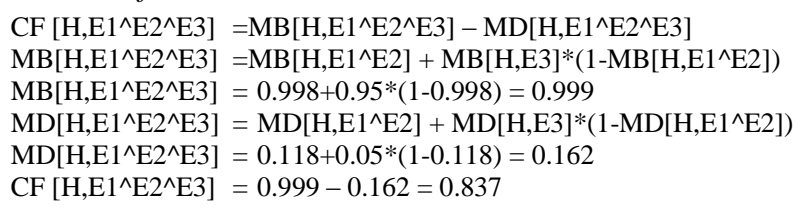

d) Determining Certainty Factor (CF) of the success of the product component caused by the aspect of effect of implementation of Civics Education as the means of character education based on local culture, and the result expected from the implementation of Civics Education.

$$
\begin{aligned}
\mathrm{CF}\left[\mathrm{H}, \mathrm{E} 1^{\wedge} \mathrm{E} 2^{\wedge} \mathrm{E} 3^{\wedge} \mathrm{E} 4\right]= & \mathrm{MB}\left[\mathrm{H}, \mathrm{E} 1^{\wedge} \mathrm{E} 2^{\wedge} \mathrm{E} 3^{\wedge} \mathrm{E} 4\right]- \\
& \mathrm{MD}\left[\mathrm{H}, \mathrm{E} 1^{\wedge} \mathrm{E} 2^{\wedge} \mathrm{E} 3^{\wedge} \mathrm{E} 4\right] \\
\mathrm{MB}\left[\mathrm{H}, \mathrm{E} 1^{\wedge} \mathrm{E} 2^{\wedge} \mathrm{E} 3^{\wedge} \mathrm{E} 4\right]= & \mathrm{MB}\left[\mathrm{H}, \mathrm{E} 1^{\wedge} \mathrm{E} 2^{\wedge} \mathrm{E} 3\right]+\mathrm{MB}[\mathrm{H}, \mathrm{E} 4] *(1- \\
& \left.\mathrm{MB}\left[\mathrm{H}, \mathrm{E} 1^{\wedge} \mathrm{E} 2^{\wedge} \mathrm{E} 3\right]\right) \\
\mathrm{MB}\left[\mathrm{H}, \mathrm{E} 1^{\wedge} \mathrm{E} 2^{\wedge} \mathrm{E} 3^{\wedge} \mathrm{E} 4\right]= & 0.999+0.98^{*}(1-0.999)=0.999 \\
\mathrm{MD}\left[\mathrm{H}, \mathrm{E} 1^{\wedge} \mathrm{E} 2^{\wedge} \mathrm{E} 3^{\wedge} \mathrm{E} 4\right]= & \mathrm{MD}\left[\mathrm{H}, \mathrm{E} 1^{\wedge} \mathrm{E} 2^{\wedge} \mathrm{E} 3\right]+\mathrm{MD}[\mathrm{H}, \mathrm{E} 4] *(1- \\
& \left.\mathrm{MD}\left[\mathrm{H}, \mathrm{E} 1^{\wedge} \mathrm{E} 2^{\wedge} \mathrm{E} 3\right]\right) \\
\mathrm{MD}\left[\mathrm{H}, \mathrm{E} 1^{\wedge} \mathrm{E} 2^{\wedge} \mathrm{E} 3^{\wedge} \mathrm{E} 4\right]= & 0.162+0.02^{*}(1-0.162)=0.179 \\
\mathrm{CF}\left[\mathrm{H}, \mathrm{E} 1^{\wedge} \mathrm{E} 2^{\wedge} \mathrm{E} 3^{\wedge} \mathrm{E} 4\right]= & 0.999-0.179=0.82
\end{aligned}
$$

From the calculation the value of CF for respondent RI to determine the degree of certainty of components evaluated in Civics Education process using CIPP is 0.82 or $82 \%$.

Following the same steps of calculation above for data from other respondents produced results as shown in table above.

\section{CONCLUSIONS}

Based on the analysis that has been made and the results of the discussion in the previous section, then some conclusions can be drawn as follows:

a) Imperatively, institutes of higher learning are one of the places for character education that is developing the nation character. The character development in the institutes of higher learning also constitutes a pillar in the institute of higher learning tridharma, i.e., education that covers curricular instructional, co-curicular and extra-curricular activities, research, and community service. In the educational activity in the classroom, the development of character is done using integrated approaches in all lectures. Especially for Civics Education, in keeping with its co-curricular mission that it develops values and attitudes, then the character development has to become the main focus that can use various strategies/methods of character education. Civics Education in the institute of higher learning, epistemologically even strengthens the basis of its ontological basis. The first content confirms the academic and ideological substantive dimensions. While the second confirms the psychopedagogical and socio-cultural dimensions of the discipline of civics education.

b) Using the CIPP model in evaluating Civics Education processes in all public and private universities in Buleleng regency makes the evaluation more objective, especially in proving local culture in developing character education.

c) Using certainty factor method in determining the extent or degree of certainty of a component that is being evaluated in Civics Education process will produce a more objective and optimal evaluation.

\section{REFERENCES}

[1] J.J. Cogan, and B.J. Derricott, Multidemensional Civic Education, Tokyo, 1998.

[2] T. Lickona, Educating for Character. New York: Bantams Books, 1991.

[3] U.S. Winataputra, Concepts and Strategies of Citizenship Education in Schools: Review of Psycho-Pedagogical. Jakarta: Directorate General of Primary and Secondary Education of the Republic of Indonesia, 2006.

[4] Bloom, Evaluation to Improve Learning. San Fransisco: McGraw Hill Book Company, 1981.

[5] I.M. Sundayana, "Implementation of Computer Assisted CIPP Model for Evaluation Program of HIV/AIDS Countermeasures in Bali," in International Journal of Advanced Research in Artificial Intelligence, Vol. 4, No. 11, 2015, pp. 27-29.

[6] D. Mardapi, Measurement, Assessment, and Evaluation of Education ( $1^{\text {st }}$ Edition). Yogyakarta: Nuha Medika, 2012.

[7] S. Arikunto, Basics of Education Evaluation. Jakarta: Bumi Aksara, 2010.

[8] Wirawan, Evaluation Theory, Model, Standards, Applications, and Profession ( $1^{\text {st }}$ Edition). Jakarta: Rajawali Pers, 2011.

[9] I.M. Sundayana, "Implementation of Computer Assisted CIPP Model for Evaluation Program of HIV/AIDS Countermeasures in Bali," in International Journal of Advanced Research in Artificial Intelligence, Vol. 4, No. 11, 2015, pp. 27-29.

[10] P. Isaki, and S.P. Rajagopalan, "The Expert System Design To Improve Customer Satisfaction," in Advanced Computing: An International Journal (ACIJ), Vol. 2, No. 6, 2011, pp. 69-84.

[11] S.T. Deepa, and S.G. Packiavathy, "Expert System for Car Troubleshooting," in International Journal For Research in Science \& Advanced Technologies, Vol. 1, No. 1, 2012, pp. 46-49.

[12] M.S. Josephine, and V. Jeyabalaraja, "Expert System and Knowledge Management for Software Developer in Software Companies," in International Journal of Information and Communication Technology Research, Vol. 2, No. 3, 2012, pp. 243-247.

[13] D.G.H. Divayana, "Development of Duck Diseases Expert System with Applying Alliance Method at Bali Provincial Livestock Office," in International Journal of Advanced Computer Science and Applications, Vol. 5, No. 8, 2014, pp. 48-54.

[14] S. Hartati, and S. Iswanti, Expert System and It's Development.Yogyakarta: Graha Ilmu, 2008.

[15] N.Y. Asabere, "mMES: A Mobile Medical Expert System for Health Institutions in Ghana," in International Journal of Science and Technology, Vol. 2, No. 6, 2012, pp. 333-344.

[16] S. Kusumadewi, Artificial Intelligence (Techniques and It's Application). Yogyakarta: Graha Ilmu, 2003.

[17] I.G.K. Kaler, Why Corpse Burned? Denpasar: Yayasan Dharma Narada, 1993.

[18] I.G.N. Gorda, Hindu Ethics and Organizational Behavior. Denpasar: Widya Kriya Gematama, 1996.

[19] Griya, Orientation Balinese Cultural Values in Development. Denpasar: Research Center of Udayana University, 1998.

[20] M. Titib, Bali Cultural values; Implementation in The Institute of Higher Learning Tridharma. Denpasar: Udayana University, 1995. 